WiOletta KILAR

Uniwersytet Pedagogiczny, Kraków, Polska

\title{
Funkcjonowanie korporacji Amazon.com w warunkach kryzysu gospodarczego
}

\section{The operating of Amazon.com corporation during the economic crisis}

\begin{abstract}
Streszczenie: Przedmiotem artykułu jest analiza funkcjonowania korporacji Amazon.com, ze szczególnym uwzględnieniem okresu kryzysu światowego. Natomiast jego celem jest wskazanie zmian potencjału ekonomicznego tej firmy oraz przedstawienie podejmowanych działań, które miały wzmocnić jej pozycję konkurencyjną i sytuację finansową podczas kryzysu gospodarczego.

Przeprowadzone badania wskazują, że badana korporacja rozwijała się w sposób szybki i stały, co przejawiało się zarówno w poziomie zatrudnienia, jak i w wynikach finansowych. Amazon.com, w przeciwieństwie do większości korporacji różnych branż, także informatycznej, nie pogorszył wyników swojej działalności z powodu kryzysu światowego.

Abstract: The paper analyses operations of Amazon.com, with a particular focus on the period of the global crisis. The aim is identifying changes in its economic potential and presenting actions undertaken by Amazon.com in order to reinforce its competitiveness and financial condition during the crisis. The research conducted showed that the corporation was growing fast and steady, as proven by the number of its staff and its financial performance. Contrary to most corporations in a variety of business sectors, performance of Amazon.com did not deteriorate as a result of the global crisis.
\end{abstract}

Słowa kluczowe: Amazon; Bezos; korporacja; kryzys

Keywords: Amazon; Bezos; corporation; crisis

WSTĘP

Kryzys finansowy i gospodarczy, który obserwowany był w ostatnich latach, wpłynął w znaczący sposób na gospodarkę światową. Ekonomiści wskazują na wiele przyczyn tego załamania, m.in. globalizację rynków, ogromną skalę długów, które były źródłem finansowania 
kredytów hipotecznych, głównie w Stanach Zjednoczonych, szybki wzrost cen aktywów, w tym cen nieruchomości, nadmierną obecność państwa w gospodarce (Rosati, 2010). Poszczególne przyczyny w mniejszym lub większym stopniu wpłynęły także na recesję w poszczególnych państwach oraz przedsiębiorstwach różnej wielkości.

W związku z tym, że korporacje ponadnarodowe są jednym z głównych elementów gospodarki światowej, gdyż zarówno organizują światową przestrzeń gospodarczą, jak też podlegają tendencjom występującym w gospodarce, szczególnie istotne jest określenie, jak kryzys wpłynął na ich działalność. Na funkcjonowanie gospodarki światowej w czasie współczesnego kryzysu wpływ miało zwłaszcza załamanie się rynków finansowych, bardzo silnie powiązanych z korporacjami wszystkich branż (Dorocki 2010; Flejterski, 2010; Kalicki, Krześniak, 2010; Kutera, Surydykowska, 2009; Michalski, 2010; Rachwał, 2009; Rosati, 2010; Zioło, 2008). Recesja na rynku globalnym przejawiała się m.in. tym, że firmy, niejednokrotnie o ustalonej pozycji, borykały się z problemami finansowymi, a niektóre nawet zbankrutowały. Większość przedsiębiorstw musiała podjąć szybkie działania, by poprawić swoją sytuację finansową, a niektóre korporacje ponadnarodowe zmuszone były do zmiany strategii rozwoju, przez co oddziaływały na lokalne rynki pracy. Zatem światowy kryzys gospodarczy wpłynął na zmianę uwarunkowań funkcjonowania i rozwoju przedsiębiorstw, w tym korporacji ponadnarodowych.

W świetle powyższych przesłanek przedmiotem niniejszych rozważań będzie analiza funkcjonowania korporacji Amazon.com, ze szczególnym uwzględnieniem okresu kryzysu światowego. Zmierzać się będzie do wskazania zmian jej potencjału ekonomicznego oraz przedstawienia podejmowanych działań, które miały wzmocnić jej pozycję konkurencyjną i sytuację finansową podczas kryzysu gospodarczego.

\section{ROZPOCZECIE DZIAŁALNOŚCI KORPORACJI}

Firma Amazon.com została założona 5 lipca 1994 roku przez Jeffa Bezosa w Seattle (stan Waszyngton), a przedsięwzięcie zostało uruchomione w lipcu 1995 roku najpierw jako księgarnia internetowa, stając się pionierem sprzedaży elektronicznej. Początkowo księgarnia nosiła nazwę Cadabra.com, jednakże stosunkowo szybko zmieniono ją na Amazon, ze względu na to, iż Cadabra.com kojarzyła się użytkownikom ze słowem cadaver, które w języku angielskim oznacza nieboszczyka. Zdecydowano się na nazwę Amazon, by kojarzyła się z rzeką Ameryki Południowej o największym średnim przepływie na Ziemi - Amazonką (Stodolak, 2009).

Amazon.com, podobnie jak wiele innych korporacji informatycznych, np. Apple czy Google, rozpoczął działalność w garażu założyciela firmy (Kilar, 2007; Kilar, 2009; Kilar, 2010; Kilar, 2011; Wajda, 2003; Wajda, 2006; Wajda, Zoričič-Wołek, 2003). Jeffrey Bezos zdecydował się na podjęcie własnej działalności po ukończeniu dwóch fakultetów na Uniwersytecie Princeton - licencjatów na kierunku elektrycznym i informatycznym. Następnie od kwietnia 1988 roku do grudnia 1990 roku pracował w Bankers Trust Company, 
stając się w lutym 1990 roku wiceprezesem tej firmy. Wówczas już planował założenie własnej firmy, lecz plany te nieco odłożył w czasie. W związku z tym, że dotychczas zajmował się finansową obsługą przedsiębiorstw, szukał pracy w firmie zajmującej się tworzeniem technologii, w której mógłby oddać się swej prawdziwej pasji, czyli tzw. drugiej fazie automatyzacji. Bezos uważa bowiem, że ,pierwsza faza automatyzacji jest wtedy, kiedy używa się technologii, by przeprowadzić te same stare procesy biznesu, ale szybciej i sprawniej [...], zaś druga faza to wprowadzanie zasadniczych zmian w podstawowym procesie biznesu i robienie rzeczy w całkowicie nowy sposób" (Spector, 2000: 21). Od grudnia 1990 roku do czerwca 1994 roku pracował jako analityk finansowy w firmie D. E. Shaw Group, w której w 1992 roku awansował na stanowisko wiceprezesa, które piastował do 1994 roku (Raport roczny, 1997: 11).

Jeffrey Bezos wykorzystał wykształcenie oraz dotychczasowe doświadczenie, tworząc własną firmę. Wybór branży, w której ulokował pieniądze, nie był przypadkowy, gdyż jako analityk rozpoznał zapotrzebowanie na istniejącym rynku. Posiadał informacje, że w 1994 roku liczba użytkowników internetu będzie wzrastała o 2-3\% w skali miesiąca, zatem zdecydował, że założy firmę internetową. Następnie sporządził listę popularnych produktów, które są kupowane, i z niej wybrał książki, gdyż ten asortyment jest bardzo zróżnicowany (Stodolak, 2009).

Wstępnie zainwestowano w tę nową w firmę 10 tys. USD, lecz właściciel, wykorzystując kontakty z poprzednich firm, zgromadził jeszcze $11 \mathrm{mln}$ USD, które pozwoliły mu stworzyć właściwą stronę internetową księgarni oraz jej silnik ${ }^{1}$.

Od początku istnienia firmy stale podejmowano inwestycje mające na celu zarówno usprawnianie pracy witryny poprzez wprowadzanie coraz to nowszych jej funkcjonalności, jak i zakup sprzętu. Bardzo szybko przyniosło to oczekiwane efekty. Już po dwóch latach działania firmy, czyli w 1997 roku, wprowadzono Amazon.com na pozagiełdowy rynek akcji NASDAQ, gdyż wejście do tego systemu jest znacznie prostsze i mniej kosztowne od wejścia na tradycyjne giełdy kapitałowe, dzięki czemu mogą w nim uczestniczyć spółki, które nie są w stanie przekroczyć barier występujących na giełdach tradycyjnych.

\section{ZMIANY ZATRUDNIENIA I WYNIKÓW DZIAŁALNOŚCI AMOZON.COM}

Szybki i stały rozwój Amazon.com przejawiał się zarówno w poziomie zatrudnienia, jak i w jej wynikach finansowych.

W latach 1996-2011 zatrudnienie w korporacji wzrosło ze 158 osób do 56200 pracowników zatrudnionych w pełnym wymiarze czasu pracy, czyli ponad 355-krotnie. Niemalże w całym okresie obserwowany był stały wzrost zatrudnienia, jedynie w latach 2001-2003 nastąpiła stagnacja na poziomie 7500 (7800) osób, co wynikało z załamania rynku przemysłu informatycznego - pęknięcia tzw. bańki internetowej oraz światowego spowolnienia

${ }^{1}$ Oprogramowanie, które odpowiada za przetwarzanie zawartości strony internetowej oraz jej elementów formatujących. 
w dziedzinie IT i związanych z nią branżach, a także ze spadków cen i negatywnych skutków ataków terrorystycznych z 11 września 2001 roku w Stanach Zjednoczonych (ryc. 1).

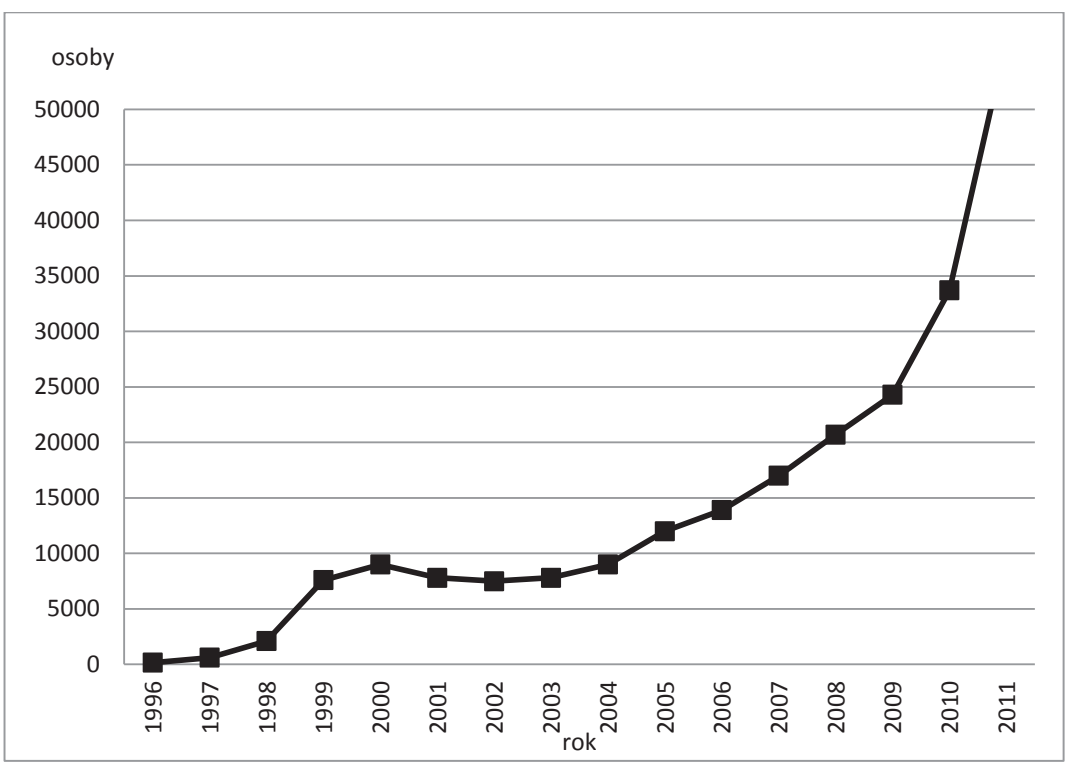

Ryc. 1. Zmiany zatrudnienia w korporacji Amazon.com w latach 1996-2011

Źródło: opracowanie własne

Analiza zatrudnienia w Amazon.com wskazuje, że kryzys gospodarczy, szczególnie odczuwalny w Stanach Zjednoczonych, nie wpłynął negatywnie na liczebność pracowników. W omawianej korporacji podwojono zatrudnienie z 20700 osób w 2008 roku do 56200 osób w 2011 roku. Poza tym w raportach rocznych korporacji podkreślane jest, że poziom zatrudnienia ulega wahaniom w ciągu roku ze względu na czynniki sezonowe mające wpływ na jej działalność. Oprócz podanej liczby pracowników stałych dodatkowo zatrudniani są niezależni wykonawcy i pracownicy tymczasowi, którzy uzupełniają braki kadrowe. Dla zatrudnionych i nowo przyjmowanych osób organizowane są intensywne kursy przygotowawcze, szczególnie dla programistów, informatyków i innych pracowników technicznych. Należy zaznaczyć, że ok. 30\% pracowników firmy zajmuje się poprawianiem funkcjonalności witryny poprzez m.in. tworzenie opisów sprzedawanych produktów (większość sprzedawców udostępnia informacje producenta) czy programów lojalnościowych.

Amazon.com charakteryzuje stały systematyczny wzrost również wyników finansowych (tab. 1). 
Tab. 1. Zmiany wartości mierników potencjału korporacji Amozon.com w latach 1995-2011

\begin{tabular}{|c|c|c|c|c|c|c|c|c|}
\hline \multirow{2}{*}{ Lata } & $\begin{array}{l}\text { Sprzedaż } \\
\text { netto }\end{array}$ & $\begin{array}{l}\text { Zysk } \\
\text { brutto }\end{array}$ & $\begin{array}{c}\text { Dochód/ } \\
\text { strata netto }\end{array}$ & Aktywa & \multicolumn{4}{|c|}{$\begin{array}{l}\text { Indeks dynamiki w latach 1995-2011 } \\
100=\text { rok wcześniejszy } \\
\text { (o podstawie ruchomej) }\end{array}$} \\
\hline & \multicolumn{4}{|c|}{ w mln USD } & $\begin{array}{l}\text { sprzedaż } \\
\text { netto }\end{array}$ & $\begin{array}{c}\text { zysk } \\
\text { brutto }\end{array}$ & $\begin{array}{c}\text { dochód/ } \\
\text { strata netto }\end{array}$ & aktywa \\
\hline 1995 & 0,5 & 0,1 & $-0,3$ & 1,1 & - & - & - & - \\
\hline 1996 & 15,7 & 3,5 & $-6,2$ & 8,4 & 3081,4 & 3391,2 & 2061,4 & 778,0 \\
\hline 1997 & 147,8 & 28,8 & $-31,0$ & 149,8 & 938,6 & 833,1 & 496,6 & 1776,7 \\
\hline 1998 & 609,8 & 133,7 & $-124,5$ & 648,5 & 412,6 & 463,8 & 401,5 & 432,8 \\
\hline 1999 & 1639,8 & 290,6 & $-720,0$ & 2465,9 & 268,9 & 217,4 & 578,1 & 380,3 \\
\hline 2000 & 2762,0 & 655,8 & $-1411,3$ & 2135,2 & 168,4 & 225,6 & 196,0 & 86,6 \\
\hline 2001 & 3122,4 & 798,6 & $-567,3$ & 1637,5 & 113,1 & 121,8 & 40,2 & 76,7 \\
\hline 2002 & 3932,9 & 992,6 & $-149,1$ & 1990,4 & 126,0 & 124,3 & 26,3 & 121,6 \\
\hline 2003 & 5263,7 & 1257,2 & 35,3 & 2162,0 & 133,8 & 126,7 & $-23,7$ & 108,6 \\
\hline 2004 & 6921,1 & 1602,0 & 588,5 & 3248,5 & 131,5 & 127,4 & 1667,9 & 150,3 \\
\hline 2005 & 8490,0 & 2039,0 & 359,0 & 3696,0 & 122,7 & 127,3 & 61,0 & 113,8 \\
\hline 2006 & 10711,0 & 2456,0 & 190,0 & 4363,0 & 126,2 & 120,5 & 52,9 & 118,0 \\
\hline 2007 & 14835,0 & 3353,0 & 476,0 & 6485,0 & 138,5 & 136,5 & 250,5 & 148,6 \\
\hline 2008 & 19166,0 & 4270,0 & 645,0 & 8314,0 & 129,2 & 127,3 & 135,5 & 128,2 \\
\hline 2009 & 24509,0 & 5531,0 & 902,0 & 13813,0 & 127,9 & 129,5 & 139,8 & 166,1 \\
\hline 2010 & 34204,0 & 7643,0 & 1152,0 & 18797,0 & 139,6 & 138,2 & 127,7 & 136,1 \\
\hline 2011 & 48077,0 & 10789,0 & 631,0 & 25278,0 & 140,6 & 141,2 & 54,8 & 134,5 \\
\hline
\end{tabular}

Źródło: opracowanie własne na podstawie raportów rocznych korporacji

Wartość sprzedaży netto (net sales) bardzo szybko wzrastała od pierwszego roku funkcjonowania, czyli od 500 tys. USD w 1995 roku do 48 mld USD w 2011 roku (ryc. 2). Zatem kryzys ogólnoświatowy nie wpłynął na omawiane wartości, gdyż w latach kryzysu i kolejnych wartość sprzedaży wzrosła ponad dwuipółkrotnie.

W raportach rocznych od 2002 roku dokonywano podziału wartości sprzedaży na trzy części: media, elektronika i inne, oraz na dwa obszary działalności: Amerykę Północną i rynek międzynarodowy.

W 2002 roku niemalże 80\% sprzedaży stanowiły media, lecz ich udział w ogóle sprzedaży systematycznie spadał na rzecz elektroniki (ryc. 3). W 2009 roku te dwa segmenty przynosiły podobny udział w sprzedaży, lecz w 2011 roku udział mediów w wartości sprzedaży wyniósł tylko 37\%, a elektroniki 60\% ogółu.

Na początku omawianego okresu 70\% sprzedaży kierowano do Ameryki Północnej (ryc. 4), lecz w ciągu dwóch lat proporcja się wyrównała i od 2004 roku połowa wpływów ze sprzedaży pochodzi z Ameryki Północnej, a druga połowa z rynku międzynarodowego. 


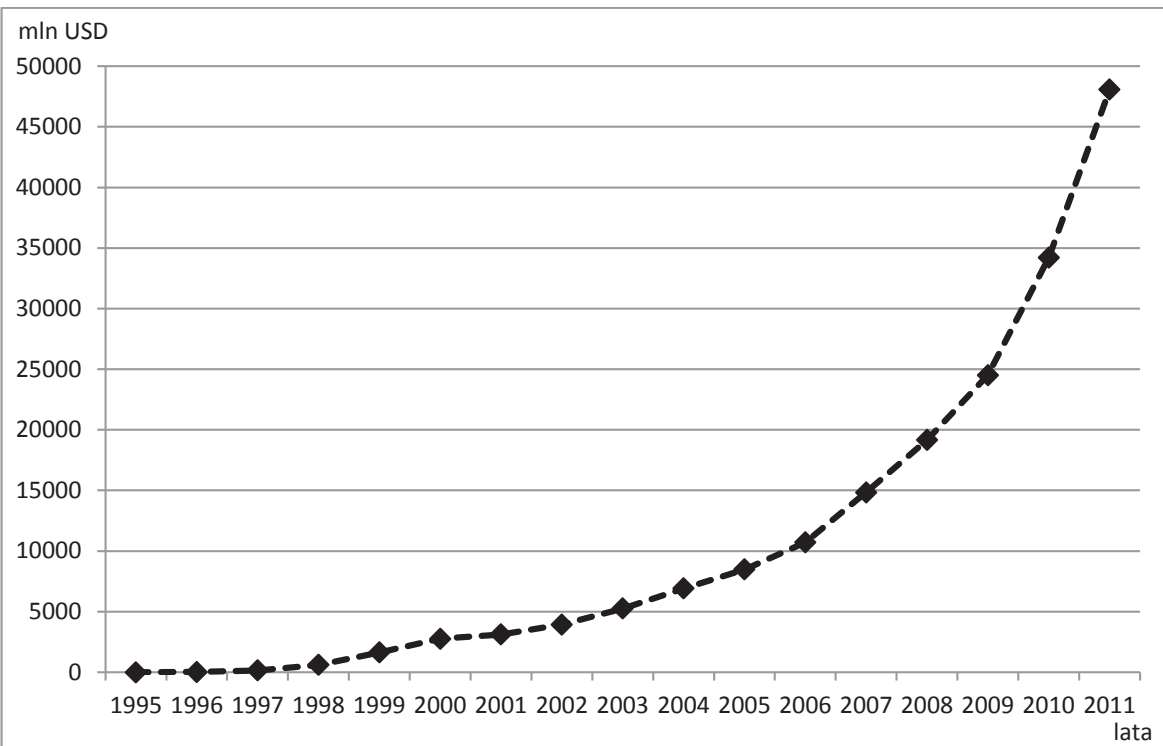

Ryc. 2. Zmiany wartości sprzedaży netto korporacji Amazon.com w latach 1995-2011

Źródło: opracowanie własne

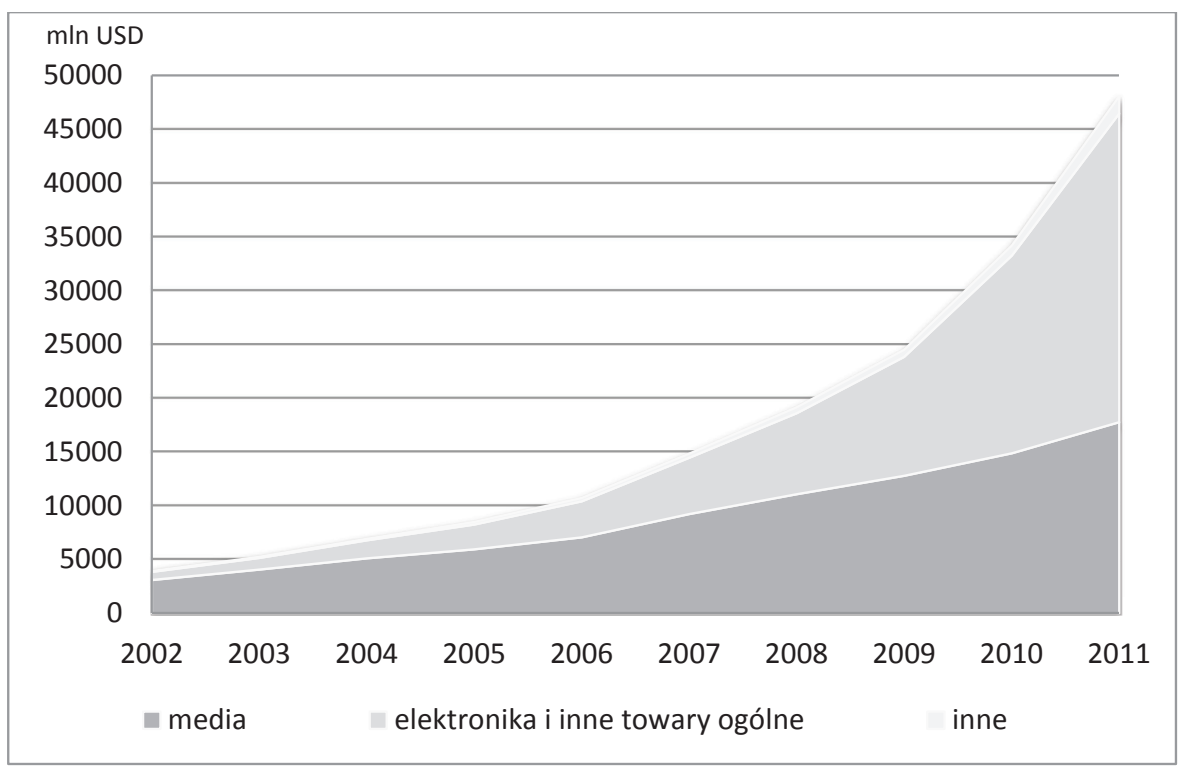

Ryc. 3. Zróżnicowanie wartości sprzedaży w korporacji Amazon.com w latach 2002-2011 wg segmentów

Źródło: opracowanie własne 


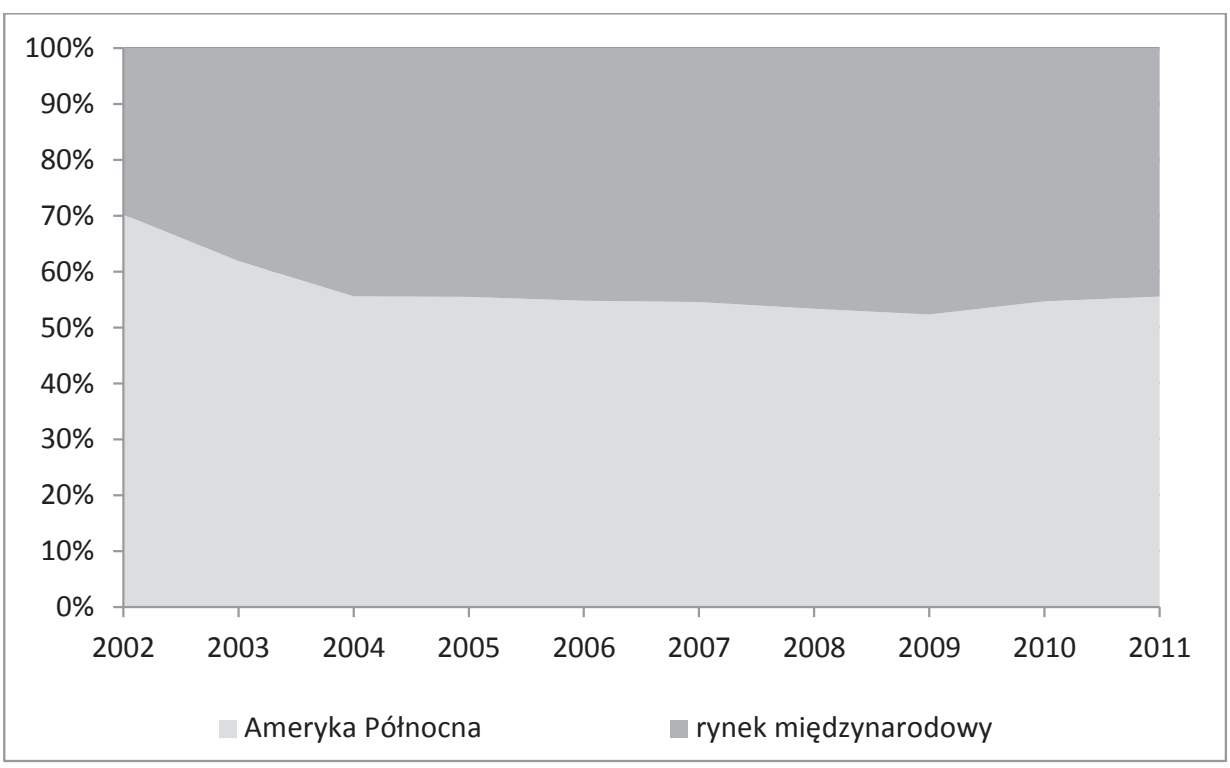

Ryc. 4. Struktura wartości sprzedaży korporacji Amazon.com w latach 2002-2011 wg obszarów działalności

Źródło: opracowanie własne

Osiągane przez korporację wyniki sprzedaży wpłynęły bezpośrednio na wartość zysku brutto, która wzrosła przez 17 lat działalności ze 100 tys. USD w 1995 roku do 10 mld USD w 2011 roku (ryc. 5). Największy przyrost zysków z roku na rok, wyrównany wartością indeksu dynamiki o podstawie ruchomej (tab. 1), zaobserwowano w pierwszym okresie działalności korporacji, czyli w latach 1995-1999, na co miało wpływ przede wszystkim poszerzanie oferowanego asortymentu. W 1997 roku korporacja oferowała 2,5 tys. tytułów książkowych, ale także płyty, kasety wideo i inne produkty (Raport roczny, 1997: 4). Współcześnie w witrynie Amazon.com można nabyć niemalże wszystko: od podstawowych produktów, czyli książek, przez płyty DVD, utwory muzyczne, sprzęt komputerowy, elektronikę, meble, po towary spożywcze i wiele innych artykułów.

Natomiast wyniki rachunków zysków i strat, czyli dochody netto, w latach 1995-2011 wahały się od 1,4 mld USD straty w 2000 roku do 1,1 mld USD dochodu w 2010 roku (ryc. 6). W początkowym okresie działalności Amazon.com, podobnie jak inne firmy, nie przynosił dochodu, a straty systematycznie rosły, co wynikało z ciągłych wydatków inwestycyjnych firmy. Największe załamanie nastąpiło w 2000 roku, kiedy to na uwarunkowania stale rozwijającej się firmy nałożyła się niekorzystna sytuacja w branży. Jednak od 2003 roku działalność przynosi dochody wahające się od $35 \mathrm{mln}$ do 1,1 mld USD. 


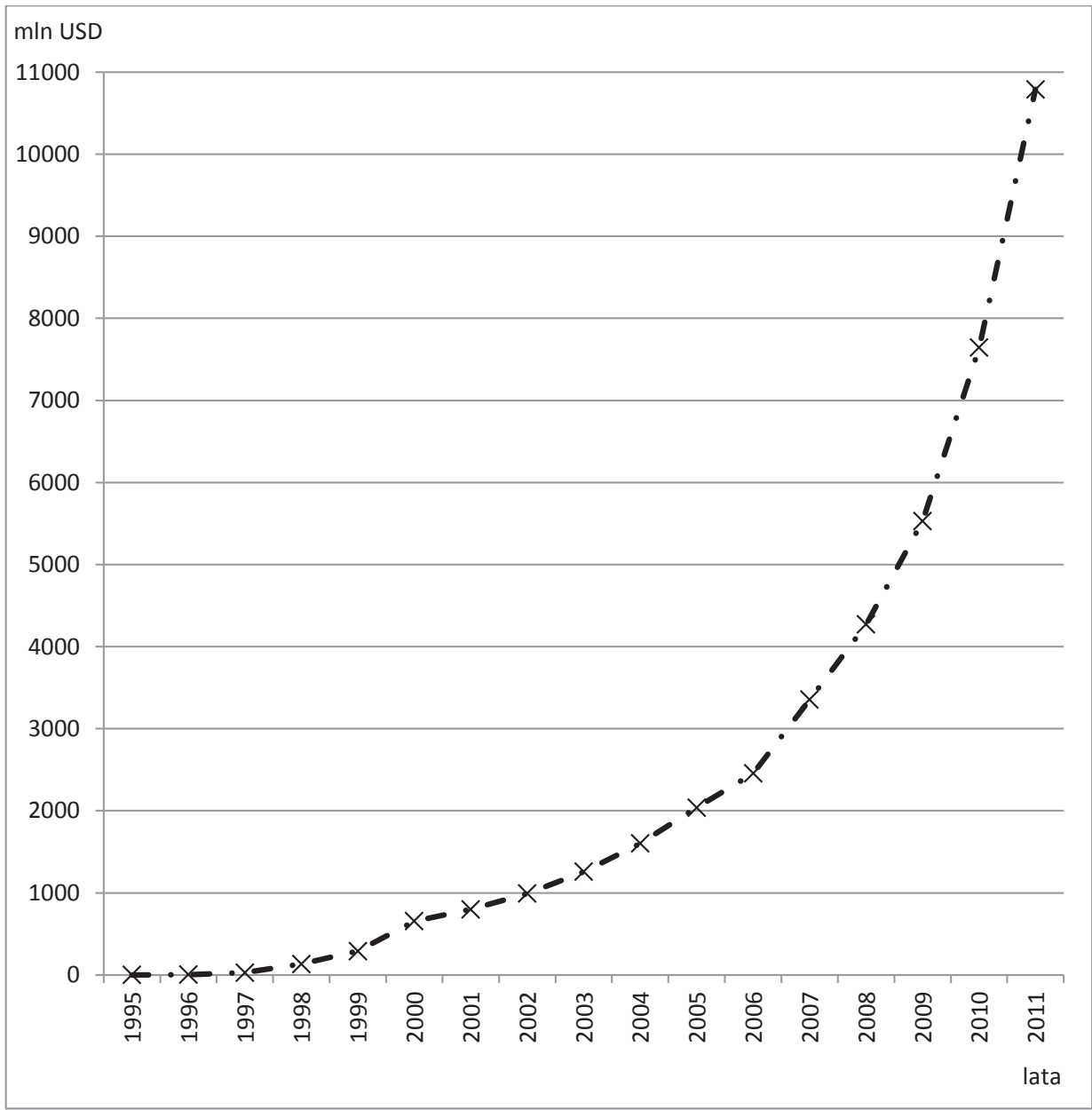

Ryc. 5. Zmiany wartości zysku brutto korporacji Amazon.com w latach 1995-2011

Źródło: opracowanie własne

Znaczne różnice dochodu netto w stosunku do zysku brutto wynikały przede wszystkim z tzw. innych wydatków operacyjnych, takich jak koszty marketingu i wprowadzania ulepszeń oraz wdrażania nowych technologii.

O wielkości korporacji świadczy także wartość aktywów, które wzrosły z 1,1 mln USD w 1995 roku do 25 mld w 2011 roku (ryc. 7). Wartość majątku Amazon.com szczególnie szybko zaczęła wzrastać w ostatnim okresie, czyli od 2007 roku, co również potwierdza, że ta korporacja oparła się kłopotom związanym z załamaniem gospodarczym na świecie. 


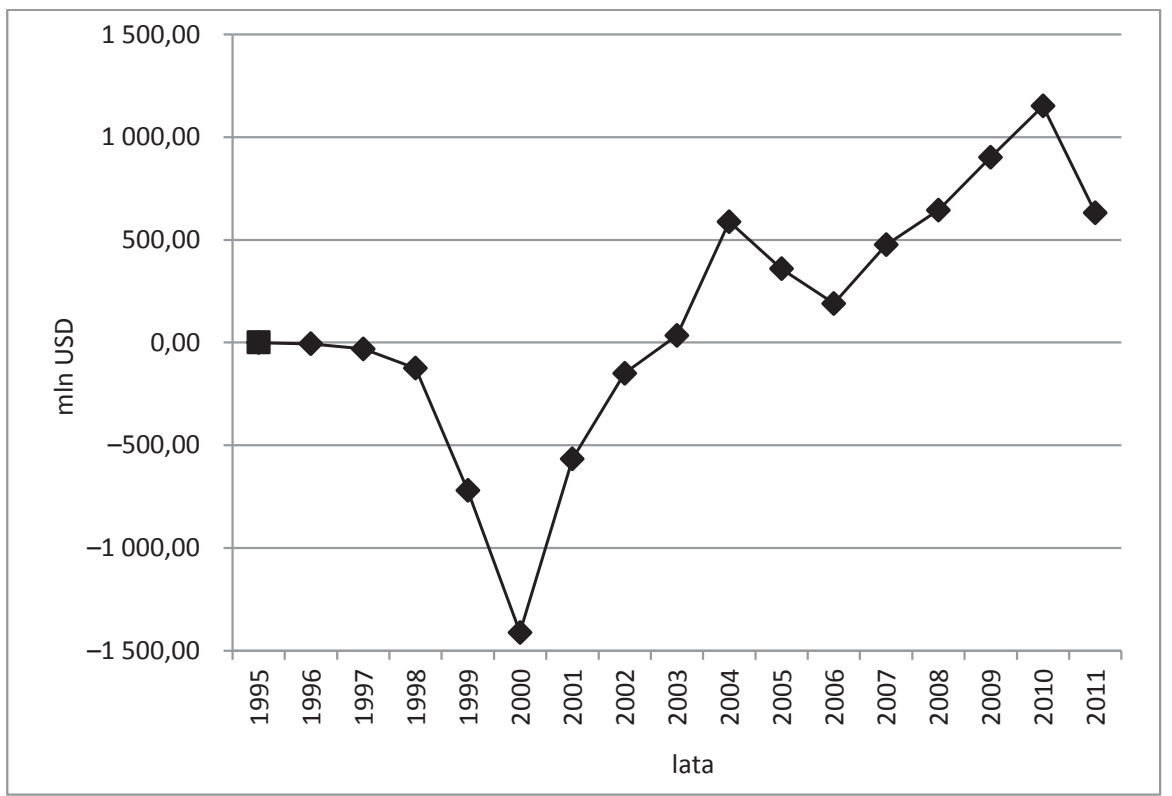

Ryc. 6. Zmiany wartości dochodów netto korporacji Amazon.com w latach 1995-2011

Źródło: opracowanie własne

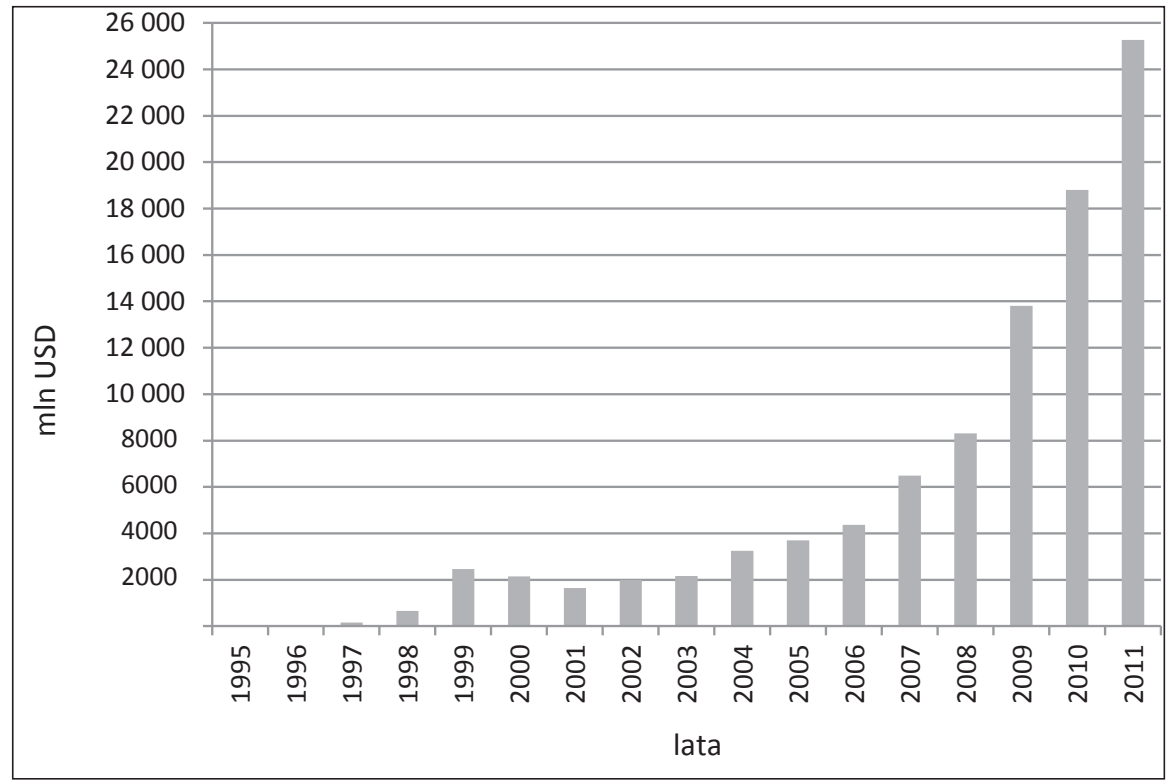

Ryc. 7. Zmiany wartości aktywów korporacji Amazon.com w latach 1995-2011

Źródło: opracowanie własne 
WNIOSKI

Z przeprowadzonej analizy wynika, że korporację Amazon.com cechował stały systematyczny wzrost wartości mierników potencjału. Na osiąganie przez Amazon.com tak wysokich wyników finansowych oraz wzrostu zatrudnienia, mimo występującego na świecie we wszystkich branżach kryzysu, miały wpływ przede wszystkim:

1. konsekwentne budowanie jednej z najbardziej rozpoznawalnych marek świata,

2. systematyczne poszerzanie asortymentu sprzedawanych towarów,

3. inwestowanie we wprowadzanie licznych funkcjonalności, które ułatwiają zakupy m.in. takich jak prezentacje poszukiwanych produktów w sposób przejrzysty i zrozumiały, dodatków do poszukiwanych produktów, towarów zakupionych przez innych użytkowników, pamięci historii zakupów każdego klienta,

4. oferowanie od 2007 roku urządzenia Kindle - własnego elektronicznego czytnika książek, wyposażonego również w wiele funkcji pozwalających m.in. na zakupy internetowe czy używanie gier interaktywnych,

5. innowacyjne pomysły marketingowe - np. Amazon jako pierwszy wprowadził program afiliacyjny, który pozwala na wysyłanie znajomym polecającego linka do produktu w sklepie, w zamian za co afiliant otrzymuje procent od sprzedaży towarów nowemu klientowi,

6. dywersyfikowanie rynków zbytu - do 1999 roku korporacja miała swoje biura i sprzedawała towary w Stanach Zjednoczonych, Wielkiej Brytanii i Niemczech, w 2000 roku otworzyła witryny we Francji i Japonii, w 2002 roku w Kanadzie, w 2006 roku w Indiach, w 2008 roku w Chinach, w 2010 roku we Włoszech i w 2011 roku w Hiszpanii; dostarczenie zamówionego towaru jest możliwe teoretycznie na całym świecie, jednak w praktyce istnieje cały system ograniczeń docelowych krajów dla danego zamówienia,

7. przejmowanie mniejszych firm specjalizujących się w pokrewnej działalności, czyli sprzedaży konkretnej grupy produktów, np. drugstore.com - sprzedający leki na receptę, kosmetyki, produkty dla zwierząt, żywność, zabawki, czy Audible - produkującej audiobooki.

Zatem korporacja Amazon.com, w przeciwieństwie do większości korporacji różnych branż, także informatycznej, nie pogorszyła wyników swojej działalności z powodu kryzysu światowego. Dzięki stosowanej strategii rozwoju w krótkim czasie stała się największym sklepem internetowym oraz wzorem biznesowego modelu w zakresie handlu elektronicznego (e-commerce). Jest również tzw. barometrem branży, gdyż zmiany sprzedaży w Amazon najczęściej odzwierciedlają zmiany w całej branży. 


\section{Literatura \\ References}

Dorocki, S. (2010). Współczesne procesy internacjonalizacji produkcji i delokalizacji przemysłu samochodowego Francji. Prace Komisji Geografii Przemystu Polskiego Towarzystwa Geograficznego, $16,125-136$.

Flejterski, S. (2010). Globalny kryzys bankowo-finansowy. Geneza, aktorzy, konsekwencje. W: G.W. Kołodko (red.). Globalizacja, kryzys i co dalej? Warszawa: Wydawnictwo Poltext, 134-154.

Kalicki, K., Krześniak, A. (2010). Polityka pieniężna w strefie euro i USA a ceny aktywów w świetle doświadczeń kryzysu. W: G.W. Kołodko (red.). Globalizacja, kryzys i co dalej?. Warszawa: Wydawnictwo Poltext, 155-185.

Kilar, W. (2007). Zarys kształtowania się korporacji ponadnarodowej Microsoft. W: I. Kiniorska, S. Sala (red.). Rola Geografii Społeczno-Ekonomicznej w Badaniach Regionalnych. Nauki Geograficzne w Badaniach Regionalnych, tom II. Kielce: Instytut Geografii Akademii Świętokrzyskiej im. Jana Kochanowskiego w Kielcach, Oddział Kielecki Polskiego Towarzystwa Geograficznego, 381-389.

Kilar, W. (2009). Rola korporacji Apple w kształtowaniu społeczeństwa informacyjnego. Przedsiębiorczość - Edukacja, 5, 48-56.

Kilar, W. (2010). Procesy kształtowania się korporacji Ericsson. Prace Komisji Geografii Przemystu Polskiego Towarzystwa Geograficznego, 16, 153-168.

Kilar, W. (2011). Wpływ kryzysu na funkcjonowanie korporacji Panasonic. Prace Komisji Geografii Przemystu Polskiego Towarzystwa Geograficznego, 17, 187-196.

Kutera, M., Surydykowska, S.T. (2009). Kryzysy gospodarcze a wiarygodność sprawozdań finansowych. Warszawa: Difin.

Michalski, R. (2010). Globalny kryzys finansowo-gospodarczy a zmiana układu sił w gospodarce i finansach świata. W: G.W. Kołodko (red.). Globalizacja, kryzys i co dalej? Warszawa: Wydawnictwo Poltext, 317-337.

Rachwał, T. (2009). Changes of industry in the countries of Central and Eastern Europe under conditions of economic transformation and european integration. W: J. Kitowski (red.). Geopolitical Studies, vol. 15. Warszawa: Wydawnictwo Instytutu Geografii i Przestrzennego Zagospodarowania PAN, $133-164$.

Raporty roczne Amazon.com z lat 1997-2011. Pozyskano z http://www.amazon.com

Rosati, D. (2010). Przyczyny i mechanizmy kryzysu finansowego w USA w latach 2007-2009. W: G.W. Kołodko (red.). Globalizacja, kryzys i co dalej? Warszawa: Wydawnictwo Poltext, 103-133.

Stodolak, S. (2009, 17 marca). Historia sukcesu sklepu Amazon.com. MamBiznes.pl. Pozyskano z http://mambiznes.pl/artykuly/czytaj/id/1090

Spector, R. (2000). Amazon.com. Historia przedsiębiorstwa, które stworzyto nowy model biznesu. Warszawa: K.E. Liber.

Wajda, E. (2003). Proces kształtowania się Motoroli jako firmy ponadnarodowej. Prace Komisji Geografii Przemystu Polskiego Towarzystwa Geograficznego, 5, 85-114.

Wajda, E. (2006). Rozwój i struktura przestrzenna działalności Nokii w latach 1997-2003. Prace Komisji Geografii Przemystu Polskiego Towarzystwa Geograficznego, 8, 219-240.

Wajda, E., Zoričič-Wołek, M. (2003). Proces kształtowania się korporacji IBM. Prace Komisji Geografii Przemystu Polskiego Towarzystwa Geograficznego, 6, 109-118.

Zioło, Z. (2008). Procesy transformacji przemysłowych układów przestrzennych na tle zmieniającego się otoczenia. Prace Komisji Geografii Przemystu Polskiego Towarzystwa Geograficznego, 10, $11-22$.

http://www.amazon.com 
Wioletta Kilar, dr, Uniwersytet Pedagogiczny im. Komisji Edukacji Narodowej w Krakowie, Instytut Geografii, Zakład Przedsiębiorczości i Gospodarki Przestrzennej. Geograf ekonomiczny. Adiunkt w Zakładzie Przedsiębiorczości i Gospodarki Przestrzennej Instytutu Geografii Uniwersytetu Pedagogicznego w Krakowie. Jej zainteresowania badawcze ukierunkowane są przede wszystkim na procesy kształtowania się i funkcjonowania ponadnarodowych korporacji, globalizacji, przemian struktur przestrzennych przemysłu oraz problematykę nauczania przedsiębiorczości i geografii w szkole.

Wioletta Kilar, Ph.D., the Pedagogical University of Cracow, Institute of Geography, the Department of Entrepreneurship and Spatial Management. She is an economic geographer. She is currently employed as an assistant professor in the Department of Entrepreneurship and Spatial Management in the Institute of Geography at the Pedagogical University of Cracow. Her research interests focus primarily on the processes of formation and operation of multinational corporations; globalization; transformation of spatial structures of industry; and issues of teaching entrepreneurship and geography in schools.

\section{Adres/address:}

Uniwersytet Pedagogiczny

Instytut Geografii

Zakład Przedsiębiorczości i Gospodarki Przestrzennej

ul. Podchorążych 2, 30-084 Kraków, Polska

e-mail:W.Kilar@up.krakow.pl 